\title{
THE CONUNDRUM OF SCHOOL DESEGREGATION: POSITIVE STUDENT OUTCOMES AND WANING SUPPORT
}

\author{
Janet Ward Schofield" and Leslie R.M. Hausmann ${ }^{* *}$
}

The Brown v. Board of Education (1954) decision was a landmark in many respects. Most importantly, it overturned the separate but equal doctrine embodied in Plessy v. Ferguson (1896), laying the groundwork for massive change in our society. In particular, it laid the basis for dismantling state supported racial segregation in education, housing, and other important areas of life. For social scientists there is another, though less important, reason why the Brown decision was so crucial. It was the first case in which a Supreme Court decision specifically mentioned the input of social science experts (Cook, 1979). Although there is a lack of agreement about how important a role this input played, social scientists were buoyed by the fact that a statement signed by a large number of leading social scientists was cited.

That statement highlighted the potentially pernicious impact of segregation on children. In the fifty years since Brown, how desegregation is likely to affect children has remained a burning issue and there has been a substantial body of research on this topic. The purpose of this paper is to briefly summarize the results of that research, which suggest, generally speaking, that desegregation has both positive academic and social consequences for students, especially African-American ones. In addition, this paper will explore why, despite such findings, we, as a society, have begun a clear retreat from school desegregation.

\footnotetext{
* Professor of Psychology and Senior Scientist, Learning Research and Development Center, University of Pittsburgh.

** Graduate student in Psychology at the University of Pittsburgh with an M.S. in Psychology.
} 


\section{The Effect of School Desegregation on Academic Achievement ${ }^{1}$}

\section{African-American Achievement}

There have been numerous reviews of the research on desegregation and African-American student achievement (Armor, 1984; Braddock \& Eitle, 2004; Bradley \& Bradley, 1977; Cook, 1984; Crain, 1984a; Krol 1978; Mahard \& Crain, 1983; Miller \& Carlson, 1984; Stephan, 1978, 1984; St. John, 1975; Schofield, 1995; Walberg, 1984; Weinberg, 1977; Wortman, 1984). Several of these, published in 1984, were meta-analyses, that is, reviews using statistical techniques to summarize the results of other studies, commissioned by the National Institute of Education. Only a handful of additional studies on desegregation and achievement of varying degrees of methodological quality have been conducted since then (Bennett \& Easton, 1988; Carsrud, 1984; Gable \& Iwanicki, 1986; Mickelson, 2001; Pride \& Woodward, 1985), and their results are generally consistent with earlier research. Thus, these reviews reflect the current state of knowledge regarding this topic quite well. ${ }^{2}$

One of these reviews, Cook (1984), includes a careful summary of the other commissioned papers. Consistent with several of the other reviews, but not all, Cook concludes that desegregation has no predictable impact on African-American students' achievement in mathematics. However, consistent with all of the other commissioned reviews that dealt with the issue, Cook also concludes that desegregation improves African-American students' reading skills. Estimates of the amount of improvement ranged from roughly two to six weeks of gain over the course of one year. ${ }^{3}$ Interestingly, some schools showed unusually large gains, suggesting that different instances of

1. Due to space constraints, this paper reviews the impact of desegregation on African-American and White students only. Readers interested in the rather small and fragmentary body of research available on desegregation's impact on Hispanic students should see Schofield, 1995.

2. There has been a recent surge in research on the effects of the social composition of schools (e.g., the racial composition and average socioeconomic status of students) on student achievement. Some of this work concludes that higher concentrations of minority students are associated with lower achievement for both White and African-American students, even after controlling for SES of the school (e.g., Caldas \& Bankston III, 1998). However, other research finds no such relationship once SES of the school has been considered (e.g., Rumberger \& Palardy, 2003). Given the present conflicting state of this literature and the fact that many of the relevant studies do not include necessary control variables, we do not discuss this work in detail. [See Rumberger \& Palardy (2003) for a more comprehensive overview.]

3. There is no evidence to justify multiplying this effect by 12 to estimate gain over a student's entire elementary and secondary career. In fact, there is some counter evidence (Mahard \& Crain, 1983). 
this process may have very different outcomes. Research suggests that desegregation may be most effective when carried out in early elementary years (St. John, 1975; Cook, 1984; Crain, 1984a; Mahard \& Crain, 1983; Stephan, 1984), when voluntary rather than mandatory (Cook, 1984; Stephan, 1984; Rossell, 1990), and when metropolitan plans are used (Mahard \& Crain, 1983).

High school graduation rates are another important measure of achievement, given that dropping out of school increases the difficulty of attaining a stable, economically secure job. A small study conducted in Texas in the year immediately following desegregation found an increase in drop-out rates, especially among males (Bryant, 1968). However, two other large, welldesigned studies reported a clear positive relation between school desegregation and high school graduation rates for African-Americans living in the North (Crain \& Weisman, 1972; Crain, Miller, Hawes \& Peichert, 1992), although the first of these found no such relation for AfricanAmericans living in the South.

The benefit of school desegregation on retention of African-American students has also been demonstrated when school desegregation occurs as a result of residential integration. A rare quasi-experiment examined a number of outcomes for low-income African-American families who received housing vouchers to move to either middle-income, predominantly White suburbs or to low-income, predominantly African-American city neighborhoods (Rosenbaum, 1995). It is important to note that families were assigned to neighborhoods as residential units became available, and therefore initial neighborhood preference had no bearing on where families ultimately moved. Pertinent to the current discussion, students who moved to the suburbs had a high school drop-out rate of 5\% compared to the drop-out rate of $20 \%$ for those who moved to city neighborhoods.

\section{White Achievement}

Understanding the impact of desegregation on White achievement is important because one of the major concerns expressed by Whites opposing desegregation is that it will undermine White children's academic progress. St. John's (1975) early review cites 24 studies of the impact of school desegregation on White achievement, many of which do not meet strict methodological standards. However, the overwhelming majority suggests no impact in either direction. This conclusion is consistent with every other summary statement on this issue of which we are aware. For example, Orfield (1978, p. 124) wrote, "[w] hat is remarkable, however, is the consistency of the 
finding that the desegregation process itself has little, if any, effect on the educational success of white students, as measured by achievement test scores . . . Researchers operating from very different scholarly and ideological starting points support this general finding."

The only two major studies of which we are aware of desegregation and White achievement not covered in the St. John review do little to change its overall conclusion. The first of these, Singer, Gerard, and Redfearn (1975), concludes, on the basis of a massive study with post-measures taken one to five years after desegregation, that desegregation has no effect on White students' achievement. The second, Patchen (1982), found some indication that White students who had attended majority Black elementary schools had lower achievement scores in high school than their peers who had attended majority White schools, but the effect was very slight. Thus, Patchen (1982, p. 303) concludes that, "there were no substantial associations between the average grades or the average achievement scores of Whites and the racial composition of their schools."

\section{The Effect of School Desegregation on Post-Secondary Outcomes}

Although academic achievement as measured by standardized test scores is important, it should not be overemphasized. Some studies find weak or non-existent relationships between such test scores and college grades, although others find more substantial associations (e.g., Baron \& Norman, 1992; Fleming \& Garcia, 1998; Geiser \& Studley, 2002; Jencks et al., 1972; Marston, 1971; McClelland, 1973). Moreover, in no study do test scores come close to being perfect predictors of college performance, leaving much room for other factors to contribute to success. In addition, test scores predict academic success less well for African-American students than for Whites, although this phenomenon may be limited to Blacks enrolled in predominantly White institutions (Fleming, 2002). Test scores have received disproportionate attention because standardized tests are widely administered and, hence, convenient. We therefore turn our attention to other important outcomes of desegregation.

\section{African-American Educational Attainment}

Reviews of the research on desegregation and the post high school educational attainment of African-Americans conclude that desegregation has a positive influence on this outcome (Schofield, 1995; Wells, 1995; Wells \& Crain, 1994). For example, Boozer, Krueger, Wolkon, Haltiwanger, and 
Loury (1992) found that the proportion of African-American students in one's high school was negatively correlated with the number of years of college completed by a national sample of African-Americans. Also, Armor (1972) reported positive effects of two small, voluntary desegregation programs on college enrollment rates, although in one case a higher college drop-out rate for the formerly desegregated students dissipated this enrollment advantage by the end of the sophomore year. Similarly, Crain, Miller, Hawes, and Peichert (1992) report that a desegregation program in Hartford, Connecticut had a positive effect on African-American males' college enrollment. In yet another study of over 3,000 African-American high school graduates, Crain and Mahard (1978) found that desegregation was positively associated with college enrollment and persistence for African-American students living in the North. However, this relationship was not statistically significant for students living in the South. This pattern of results was later corroborated by Braddock and McPartland (1982).

\section{African-American Occupational Aspirations and Attainment}

Recent reviews of the long-term outcomes of desegregation (Schofield, 1995; Wells, 1995; Wells \& Crain, 1994) also suggest that desegregated African-American students have higher occupational aspirations than their peers who attend segregated schools. For example, Wells and Crain (1994) point out that evidence from three of the four studies on this topic that control variables known to influence occupational attainment and focus on desegregation plans that preclude self-selection supports this conclusion (Dawkins, 1983; Falk, 1978; Gable, Thomspon, \& Iwanicki, 1983; Hoelter, 1982). St. John's (1975) earlier review suggested no clear link between desegregation and occupational aspirations. However, many of the studies cited by St. John did not include important control variables, and thus are hard to interpret.

Desegregation also seems to encourage majoring in fields that prepare African-Americans for careers in which they have traditionally been markedly underrepresented (Braddock \& Eitle, 2004). For example, using national longitudinal survey data from more than 3,000 African-American high school students, Braddock (1987) found that those who had attended predominately White high schools were more than four times as likely to have selected a college major in computer and information sciences, fields in which AfricanAmericans are woefully underrepresented (Vardi, Finin, \& Henderson, 2003), than those who had attended segregated high schools. Furthermore, Crain and Strauss (1985) found that African-Americans who attended desegregated 
schools were more likely than their segregated peers to work in high status, white collar jobs in the private sector, although this trend appeared markedly stronger for females than males.

Desegregation can also have a positive impact on job attainment for African-Americans, although it does not do so consistently. Crain and Weisman (1972, p. 161) concluded that "[a]lumni of integrated schools are more likely to move into occupations traditionally closed to Blacks; they also earn slightly more money, even after education is controlled" (Crain \& Weisman, 1972, p. 161). However, Trent (1991) failed to replicate this finding, and another study by Crain and Strauss (1985) concluded that desegregation did not have a direct impact on the occupational attainment of African-American males without a college education, although it did have a positive effect on that of their female peers. A more recent longitudinal study that only examined the wages of males reported an association between attending desegregated schools and earning higher wages approximately five years after graduation (Grogger, 1996). This is consistent with Boozer et al.'s (1992) finding that the proportion of African-American students in their former schools was negatively related to adult African-Americans' hourly wages. Finally, a large-scale study by Dawkins (1991) found a modest positive link between attending a desegregated high school and later occupational attainment for African-Americans, although regional and age cohort differences were apparent. ${ }^{4}$

The racial composition of the college African-American students attend also has implications for their occupational attainment. A review of studies on this topic concludes, "[o]n balance, black graduates (especially males) of predominantly white institutions seem to receive labor-market advantages over those from predominantly black institutions" (Braddock, 1985, p. 18). This may be due, in part, to the fact that desegregated social networks positively influence job attainment (Braddock \& McPartland, 1987). It could also be partially because some employers tend to derogate degrees received from Black institutions and to prefer Black graduates from desegregated White institutions (Braddock \& McPartland, 1983; Crain, 1984b; McPartland \& Crain, 1980).

4. Employers show relatively favorable attitudes toward hiring minority group graduates of suburban high schools (Braddock, Crain, McPartland, \& Dawkins, 1986). Thus, desegregation efforts that transfer students from urban to suburban settings would presumably have positive job market consequences for the minority students involved, above and beyond any impact it might have on their academic achievement. 
In summary, attending desegregated schools often appears to have a positive impact on the jobs African-Americans get. Although the evidence is sparse and this impact is moderated by both region and gender, this outcome is of real importance given that occupational attainment is crucial for an individual's social position and economic well-being.

\section{Adult Social and Professional Networks}

Studies of the short-term impact of school desegregation on intergroup attitudes show mixed results. Indeed, the overall conclusion emerging from reviews of this literature is that the impact of desegregation on short-term changes in attitudes and behaviors is likely to depend heavily on the nature of the particular experience that students have in that environment (Schofield, 1991, 2004a).

Studies of desegregation's long-term effects on intergroup relations are clearer. Specifically, in the long run, desegregation seems to help break down racial isolation (Braddock \& Eitle, 2004; Wells, 1995; Wells \& Crain, 1994). For example, African-Americans who attended desegregated schools are more likely to report living in integrated neighborhoods and/or having White social contacts later in life than their segregated peers (Crain \& Weisman, 1972; Dawkins, 1991). Further, there is a positive relation between years of desegregated schooling and acceptance of residential integration for White high school seniors (Johnson, 1990). However, this same relationship was not found for their minority group peers. Furthermore, a recent study of White adults (Wood \& Sonleitner, 1996) concludes that childhood interracial contact in schools and neighborhoods dispels racial stereotypes and reduces antiBlack prejudice. This is consistent with evidence that Whites in desegregated schools often show a decrease in their initial fear and avoidance of AfricanAmericans, and an increasing willingness and ability to work with them (Noblit \& Collins, 1981; Schofield, 1989). Studies such as these suggest mechanisms that might help to account for the impact of school desegregation on Whites' later acceptance of racially-mixed social environments.

School desegregation also appears to break down intergroup isolation in employment as well (Braddock \& Eitle, 2004). Specifically, Braddock, Crain, and McPartland (1984) review the results of several national surveys and conclude that African-American graduates of desegregated schools are more likely to work in desegregated environments than their peers who attended segregated schools. Similarly, Braddock and McPartland (1989) conclude that young African-American adults who had attended desegregated high schools were more likely than their previously segregated peers to have White co- 
workers. Furthermore, two studies have demonstrated that the racial composition of White students' high schools or colleges influences the likelihood that they will work in a desegregated setting later in life (Braddock, McPartland, \& Trent, 1984; Trent, 1991). Indeed, Trent's (1997, p. 256) examination of national longitudinal survey data suggests that, "school racial composition has a strong, statistically significant, and positive effect on the likelihood that Blacks will have White coworkers, and that Whites will have Black coworkers."

Desegregated schooling may not only affect one's propensity to work in racially-mixed settings but also one's reactions to this experience. Specifically, Trent (1991, p. 35) concludes "that Black, Latino, and White graduates of segregated schools perceive racially-mixed work groups as less friendly than racially-homogeneous ones.... Respondents from desegregated schools make ... much less of a distinction. ... This suggests that desegregated school experiences can reduce negative feelings toward coworkers of other ethnic groups."

\section{The Retreat from School Desegregation}

As the above review of the research suggests, desegregation appears to have had numerous positive effects on student outcomes. These effects are not strong and they are not guaranteed-but the preponderance of evidence suggests that they do often occur. In light of this, it is ironic that the U.S. is in full retreat from the policy of school desegregation. After briefly discussing the basis for the assertion that the U.S. is retreating from desegregation, we consider some of the factors contributing to this situation.

Schools in the U.S. have undoubtedly become more segregated in the past fifteen years (Orfield, 2001). Indeed, Frankenberg, Lee, and Orfield (2003, p. 6) conclude that during the 1990s "the proportion of Black students in majority White schools decreased ... to a level lower than any year since 1968." Part of this increase in segregation is no doubt related to the changing demographics in our country, differential birth rates in different racial and ethnic groups, large-scale migration into the U.S., the flow of Whites from cities to the suburbs, and other long-term social trends. However, part of it is clearly also due to a retreat from the policy of school desegregation. For example, Reardon and Yun (2003) demonstrate that during the 1990s school segregation in the South increased at the same time that residential segregation decreased.

Although considerable progress was made in desegregating schools in the late 1960s and the 1970s, by the 1980s the Reagan Justice Department was 
asserting that desegregation was a failed policy, and a number of cities began to explore how they could dismantle their desegregation plans (Orfield \& Eaton, 1996). Then, in the early 1990s, in the Dowell v. Board of Education (1991) and Freeman v. Pitts (1992) decisions, previously segregated school districts under desegregation orders were declared to have achieved unitary status. Basically, in such cases, districts that had been segregated were released from desegregation orders once it was decided that they had dismantled their segregated systems and replaced them with desegregated ones. This opened the door to resegregation because once districts had been declared unitary, the courts were free to "presume any government action creating racially segregated schools to be innocent, unless a plaintiff prove[d] that the school officials intentionally decided to discriminate" (Orfield \& Eaton, 1996, p. 19). This is a difficult task to achieve even if the actions were undertaken with such an intent. Since those important Supreme Court decisions, large numbers of districts, including Dallas, Norfolk, and Oklahoma City, have been declared unitary, permitting them to undertake actions that would previously have been illegal and which have the effect of resegregating their schools.

Why is it that there appears to be such general acceptance of the dismantling of desegregation as a social policy and such widespread acceptance of, or indifference to, the fact that schools are becoming resegregated? No doubt the answers to this question are many and complex. Below, we provide an overview of several possible reasons.

\section{Reasons for the Retreat from School Desegregation}

\section{Low Initial Support for Desegregation and Opposition to Implementation Strategies}

Attempts to implement school desegregation have never had broad and deep support among the majority of the American public. Indeed, the Supreme Court recognized the depth of resistance by Whites to efforts to achieve desegregation when in a follow-up decision to Brown v. Board of Education (Brown II) (1955, p. 301) it allowed implementation to proceed "with all deliberate speed" rather than requiring rapid change. Over the years since this decision, however, social norms have changed and White racial attitudes have became markedly more liberal (Blauner, 1989; Schuman, Steeh, Bobo, \& Krysan, 1997). The widespread dramatic resistance to desegregation that characterized the years immediately following Brown has all but disappeared. Indeed, in recent decades a substantial and rising proportion of 
Whites respond to survey questions in ways that indicate support for desegregation in the abstract. For example, whereas in 1942 only $32 \%$ of a national sample of Whites said that White and African-American students should attend the same schools, $96 \%$ of a similar sample responded in such a way in 1995 (Schuman et al., 1997).

If the overwhelming majority of Americans support the policy of school desegregation as polls suggest (Schuman et al., 1997), one might expect an outcry from the public opposing the clear movement away from desegregation. However, the retreat from desegregation is not being protested by the majority of Americans. What might explain this willing acceptance of the demise of desegregation?

One explanation could be that, currently, desegregation is simply not considered an important issue by many Americans. Indeed, an increasing percentage of both Whites and African-Americans report having no interest in the issue of whether the federal government ensures that schools are integrated (Schuman et al., 1997). The percentage of Whites and AfricanAmericans who reported having no interest in this issue was $11 \%$ in 1964. This percentage had tripled or nearly tripled, respectively, for both Whites (34\%) and Blacks (31\%) by 1994 (Schuman et al., 1997). The lack of opposition to the retreat from desegregation may then be due, in part, to a lack of interest in the issue among the public. The kinds of factors that lead to segregation of the schools today tend to be more subtle than before the Brown decision. Once the flagrant dual school systems of an earlier era were dismantled, targets that symbolized racial injustice and oppression disappeared and were replaced by the kinds of segregation that could have causes other than racism. Such segregation, stemming from a variety of complex factors, is less likely to arouse the conscience of the public. Hence, it may stimulate less interest and concern among the general public.

Another related explanation for the widespread acceptance of our nation's retreat from desegregation is that those individuals who report supporting the principle of school desegregation in surveys do not value it enough to support spending the resources required to ensure its implementation. Indeed, a large majority of Whites still oppose most of the policies that are required to achieve desegregation (Schuman et al., 1997). For example, according to national surveys in $1972,87 \%$ of Whites opposed busing, one of the primary strategies used to achieve desegregation, and 67\% opposed it in 1996 (Schuman et al., 1997). Another national survey reported by Schuman et al. (1997) found that the proportion of Whites who approved of busing hovered around 5\% from 1972 until 1984 when the pertinent question was removed from that survey. 
Interestingly, Whites may oppose implementation strategies even more as the likelihood of those strategies being carried out increases, suggesting that reported support for implementation may over-estimate actual support. A study conducted in Connecticut compared White attitudes to various approaches to implementing desegregation in 1990, immediately after the filing of Sheff v. O'Neill, a civil action calling for desegregation, and in 1996 when this case was decided in favor of the plaintiffs. Whites' support for busing and other approaches to achieving desegregation dropped markedly during that time period (McMiller, 2000). The only desegregation policy that garnered support from the majority of Whites and that became more popular over time with them was the creation of magnet schools (McMiller, 2000). Attendance at such schools is voluntary, so individuals can support them in principle without having their children directly affected by them.

The widespread lack of approval of the means necessary to achieve desegregation helps to explain why there is not much protest to the discontinuation of desegregation. The task, then, becomes explaining why Whites, who in principle report favoring desegregation, oppose the means of implementing it. Two explanations for this phenomenon, racism and selfinterest, have been the subject of considerable research.

\section{Racism as an Explanation for Opposition to Implementation of Desegregation}

Given that racism contributed greatly to the original creation of the dual school systems that desegregation was meant to dismantle, it is not surprising that some suggest that racism continues to contribute to resistance to implementing desegregation. However, the expression of overt racism has declined considerably in recent decades (Schuman et al., 1997) without a correspondingly large rise in the acceptance of strategies designed to achieve desegregation. This apparent contradiction might be resolved by pointing out the distinction between old-fashioned racism and more modern forms of racism (McConahay, 1986). Old-fashioned racism refers to traditionally recognized racist views based on the belief that one group is biologically superior to another. Modern forms of racism are more subtle. For example, symbolic racism, one form of modern racism, includes the belief that AfricanAmericans are no longer discriminated against; therefore, they should work harder if they wish to improve their status in life, and they do not deserve special aid from the government (Sears, Van Laar, Carrillo, \& Kosterman, 1997). 
Social norms have changed in the United States over the past 50 years so that it has become increasingly unacceptable to express old-fashioned racism. There has undoubtedly been a true decline in traditional racism. But changed norms also means that some people may fail to acknowledge their racist beliefs and behaviors to researchers, making it hard to document connections that exist between racism and attitudes to various strategies intended to produce desegregation. However, there has not been a similar change in the norms surrounding modern racism, perhaps because beliefs deemed as reflecting modern racism can have non-race-related justifications. For instance, the belief that African-Americans should work harder if they wish to improve their status in life could be seen as reflecting the American values of independence and hard work rather than the overtly racist belief that African-Americans are lazy. A social milieu that discourages old-fashioned, but not modern, racism has created a situation in which it is easy for Whites to say they support desegregation in principle but not its implementation. Specifically, the support for desegregation in principle may reflect either a decline in or suppression of old-fashioned racism, and the resistance to specific desegregation implementation plans may reflect a modern, more subtle form of racism.

Numerous studies have found both old-fashioned and symbolic racism to be directly correlated with opposition to busing (Erbe, 1977; McConahay, 1982; Sears, Hensler, \& Speer, 1979; Sears, Lau, Tyler, \& Allen, 1980; $c f$. Kelley, 1974), although symbolic racism typically shows a considerably stronger link (McConahay, 1982). Similar patterns of results are also found in studies that examine the unique roles of old-fashioned and symbolic racism in support for equal opportunities for African-Americans and for race-based policies such as affirmative action (Sears et al., 1997; Williams et al., 1999).

Other studies find no direct link between racism and opposition to busing, but find that they are indirectly related nonetheless. For example, although McClendon (1985) found no direct link between racism and opposition to busing he concluded that racism was linked to the perceived costs of busing, which in turn predicted opposition to busing. Similarly, Gatlin, Giles, and Cataldo's (1978) study of the determinants of people's approval of how desegregation had been "handled" in seven Florida school districts found that racial prejudice was only indirectly associated with approval for the handling of desegregation. Specifically, prejudice was negatively correlated with endorsement of the goal of integration and support for the government's right to see that desegregation occurs, and these variables were correlated with support for the handling of desegregation. Overall, then, substantial research 
suggests that racism is related to opposition towards implementation of desegregation plans, even if in some cases only indirectly.

\section{Self-interest as an Explanation for Opposition to Implementation of Desegregation}

Rational choice theory (e.g., Armor, 1995; Rossell, 1995) posits that people consider the costs and benefits of a particular line of action and make a rational decision that leads to more benefits than costs for themselves. This line of research suggests that support for desegregation implementation strategies, such as busing, arises when desegregation is perceived to be in a person's self-interest.

A great deal of research has attempted to sort out whether perceived selfinterest is indeed a determinant of attitudes toward desegregation implementation strategies, most notably busing. In such studies, typically conducted with White participants, self-interest is typically defined in terms of how likely a person, or that person's child, is to be directly affected by a desegregation busing plan. McConahay (1982) found a small but significant correlation between self-interest and opposition to busing among Whites. When racial attitudes were controlled, however, that relationship disappeared. This is consistent with a host of studies that have found little to no support for the proposition that self-interest contributes to opposition towards busing (Gatlin et al., 1978; Kelley, 1974; Kinder \& Rhodebeck, 1982; Kinder \& Sears, 1981; Sears et al., 1979, 1980). This led Green and Cowden (1992, p. 473) to declare that self-interest "has more or less dropped out of the competition" as an explanation for Whites' attitudes toward busing.

Although the evidence is indeed predominantly unsupportive of selfinterest as an explanation for Whites' negative attitudes toward busing, in two different sets of data Green and Cowden (1992) found a strong, consistent positive relationship between common measures of self-interest and whites' participation in actual anti-busing activities such as attending meetings of antibusing organizations. One of these data sets was the focus of McConahay's 1982 study, in which negligible support for a link between self-interest and busing attitudes was found when controlling for racism. Unfortunately, Green and Cowden (1992) did not control for racism in their analyses so it is not possible to determine whether the effects they report would be attenuated if racism were taken into account. Overall, then, self-interest is not an important explanatory variable in White's attitudes towards busing. However, it does predict action to protest busing, although this conclusion is based on a single study and is therefore tentative. 
Whites' Belief That the Socioeconomic Gap Between Whites and AfricanAmericans Stems from African-Americans' Lack of Ability or Motivation

Another factor contributing to the retreat from desegregation as a social policy is that during the $1980 \mathrm{~s}$ an increasing proportion of the White public began to disapprove of race-targeted government programs designed to decrease inequality (Wilson \& Braddock, 1997). Perhaps due to the fact that Civil Rights laws were passed more than a generation ago, Whites now generally see no pressing need to bring about desegregation because they see little need for government action designed to help improve AfricanAmericans' undeniable educational and occupational disadvantage. This stance is related to the fact that, in spite of clear evidence that discrimination still exists (Feagin, 2000), most Whites see African-Americans' disadvantage as flowing from African-Americans' lack of motivation (Schuman \& Krysan, 1999), which undercuts Whites' sense of responsibility for supporting efforts to improve opportunities for African-Americans through policies like school desegregation. Furthermore, this perspective makes desegregation seem unlikely to be a viable route to improving educational and occupational outcomes for African-Americans because motivation is commonly understood as a personal characteristic.

Whites place the responsibility for African-Americans' generally low socio-economic status squarely on the backs of African-Americans themselves, rather than attributing it to current or past discrimination. For example, roughly two-thirds of the White public believes that AfricanAmericans' lack of ability and/or motivation accounts for the gap in socioeconomic status between Whites and African-Americans (Kluegel, 1990). Only $30 \%$ attribute this gap to structural factors, such as discrimination or poor education. Indeed, over $70 \%$ of White Americans believe that African-Americans have an average or better than average chance of "getting ahead" (Kluegel \& Smith, 1982). Indeed, Kluegel and Smith (1982) concluded that, in general, Whites deny the existence of structural limits to African-Americans' opportunities. A more recent study using data from Gallup polls concluded that, "whites tend to place responsibility mainly on blacks themselves, with the primary emphasis on a presumed lack of motivation" (Schuman \& Krysan, 1999, p. 847). Only 14\% of Whites hold Whites responsible for African-Americans' disadvantage. In contrast, 56\% blamed African-Americans themselves, with 23\% blaming both groups.

Studies have found that such beliefs are associated with policy preferences. Specifically, Kluegel (1990) found that Whites who attributed 
African-Americans' relatively low levels of income and job attainment to discrimination were more than five times as likely to support greater government spending on efforts to improve conditions for Blacks than were those who attributed it to ability or motivation. Even more strikingly, they were eight times as likely to say that the government should be making special efforts to improve African-Americans' standard of living. Bobo and Kluegel (1993) found that the belief that the socioeconomic gap between Whites and African-Americans is due to discrimination was positively correlated with support for policies designed to enhance or equalize opportunity for AfricanAmericans. They also found that the belief that the socioeconomic gap is due to African-Americans' lack of motivation was negatively correlated with support for such policies. Although these studies do not deal with attitudes towards desegregation, specifically, they do deal with similar race-related policies. It therefore seems reasonable to posit that the lack of opposition to the retreat from desegregation may also be partially explained by Whites' attributions for African-Americans' position in society.

\section{Disproportionate Distribution of the Burdens of Desegregation}

Although African-Americans led the initial push for desegregation, they have not strongly mobilized in the last decade or two to oppose the retreat from it. Indeed, some voices in the African-American community have spoken out against desegregation as it has commonly been implemented (Adair, 1984; Bell, 1980, 1987; Days, 1992). Although African-American discontent with desegregation has sometimes been exaggerated, it is clear that African-Americans are not unified and organized in a fight against the discontinuation of desegregation, in spite of the evidence suggesting numerous positive outcomes for students. In this section we review some reasons for this situation.

School desegregation has often been carried out in a way that laid a substantial and disproportionate share of the costs of this policy on the shoulders of the African-American community. This fact is fundamental in explaining why many African-Americans have accepted a retreat from desegregation with relative equanimity. These costs came in many forms. First, desegregation resulted in the closing of a disproportionate number of historically Black schools (Adair, 1984; Days, 1992; Harris, 1983) which brought with it a host of problems for African-Americans. Such schools often served as important institutions in African-American communities and their closing left a void in many communities (Dempsey \& Noblit, 1993; McCullough-Garrett, 1993; Savage, 2001). Also important was the loss of the 
schools as socializing agents for African-American children. The teachers at African-American schools served as role models for children and often worked to instill in them qualities such as resiliency and racial pride (Goetz \& Breneman, 1988; McCullough-Garrett, 1993; Savage, 2001; Walker, 1996). In contrast, in desegregated schools African-American children have often met a colorblind perspective in which their racial heritage and cultural background have been largely ignored (Boateng, 1990; Rist, 1978; Schofield, 2004b). This lack of attention on the part of teachers in predominantly White schools to the special issues confronting African-American children has been cited as a major shortcoming of desegregation (Lomotey \& Fosey, 1997; Boateng, 1990), as has the pressure for African-American children to assimilate to a school culture based on the norms of White society (Brown, 1996; Johnson, 1993).

The closing of African-American schools also resulted in a substantial reduction in the number of African-Americans employed as teachers and principals (Abney, 1980; Adair, 1984; Ethridge, 1979; Hudson \& Holmes, 1994). For example, by 1970 over 31,000 teaching positions that would have been filled by African-Americans were lost due to desegregation (Ethridge, 1979). Similarly, even though the number of new schools increased in many districts in Florida between 1964 and 1976 as desegregation moved forward in that state, the number of African-American principals typically declined (Abney, 1980).

The African-American students who participated in desegregation programs also frequently bore a disproportionate share of the burden (Adair, 1984; Days, 1992; Harris, 1983; Wells \& Crain, 1997). For example, busing plans were most often one-way, meaning that African-American students endured long bus rides to predominantly White schools with substantially less busing of White students (e.g., Harris, 1983). One-way busing also created a roadblock for the involvement of African-American parents in the education of their children due to the difficulties it created regarding obtaining transportation to the schools (Harris, 1983).

Finally, numerous and often unanticipated consequences of desegregation, known as second- and third-generation problems of desegregation, have also influenced African-American support for desegregation. For instance, African-American students are typically overrepresented in low ability or special education groups and likewise underrepresented in high ability groups and gifted programs (Adair, 1984; Carter, 1982; Chunn, 1989; Ehrlander, 2002; Ford, 1995; Wells \& Crain, 1997). Similarly, it is common for African-American students in desegregated schools to get suspended more often than would be expected based on their 
representation within the student body (Adair, 1984; Ehrlander, 2002; Harris, 1983), although it has been argued that this disparity is not necessarily due to discrimination (Achilles, 2002). In addition, although academic gains have been made for African-American students as a result of desegregation, there continues to be a marked achievement gap between African-American and White students (Ehrlander, 2002; Miller, 1995; Ogbu, 2003). Whereas this achievement gap moves some African-Americans to fight against school districts that petition the courts to be released from their desegregation plans (Ehrlander, 2002), it also looms large in the minds of those African-Americans who do not support desegregation (Bell, 1989; Days, 1992). Indeed, the number one reason given in a survey by African-Americans for opposing busing was that quality of education was the most important issue at hand, and busing was not necessarily the best avenue to increase educational quality (Schuman et al., 1997).

In sum, the disproportionate costs of desegregation that AfricanAmericans have carried, unforeseen problems for African-American students within desegregated schools, and the persistence of a Black-White achievement gap all contribute to the fact that African-Americans have not voiced widespread discontent with society's retreat from desegregation.

\section{Demographic Shifts Make Desegregation Less Salient}

The retreat from desegregation during the past two decades has also been facilitated by striking demographic shifts in the nation. For two decades after the Brown decision, in the heyday of desegregation efforts, African-Americans were undoubtedly the largest and most politically active minority group in the country. The Civil Rights movement, Dr. Martin Luther King's assassination, the rise of the Black Panthers, and widespread urban riots made the issue of race, and the need to find constructive solutions to the problems caused by centuries of discrimination against African-Americans, obvious. The highly publicized conclusion of the United States Kerner Commission, set up to investigate the cause of those riots, that the U.S. was "rapidly moving toward two increasingly separate Americas" (1968, p. 407), one African-American and one White, is an example of the extent to which the focus on AfricanAmericans and on their relation to the White populace prevailed, with relatively little attention being paid to other groups. Desegregation initially was, and still is, widely understood as a mechanism for dealing with the segregation of African-Americans. During the past two decades, massive immigration has changed the composition of the U.S. population in ways that have made desegregation a less salient issue than it was previously. The 
proportion of individuals in the U.S. with Hispanic heritage has grown dramatically, as has the number of immigrants from areas as disparate as China and the South Pacific (Gibson \& Jung, 2002). Demographic shifts have occurred in an even more pronounced way in the schools than in the general population (Artiles, Trent \& Palmer, 2004).

Such changes have shifted the focus of attention in policy debates regarding the schooling of majority and minority students "From Desegregation to Diversity," as suggested by the theme of one of the many special events held to commemorate the Brown decision. The fact that a high proportion of immigrant children do not speak English as a first language has added a new dimension to discussions about the education of minority students. Indeed, this fact complicates desegregation efforts because common approaches to second language instruction often function most efficiently when students speaking the same native tongue learn English in each other's company, rather than when dispersed through a school system in relatively small numbers per school. African-Americans are no longer the country's largest minority group, and many other groups give relatively high priority to instruction in their first language and/or to second language instruction for their children, which changes the terms of the debate concerning education for minority group children. It is possible to pursue desegregation and second language instruction simultaneously (Bikle, Hakuta, \& Billings, 2004; Heleen, 1987). However, the original rationale for desegregation, as a mechanism for undoing state-sponsored segregation, does not fit readily into debates regarding the education of newly arrived immigrant children, although many such children would be considered members of a minority group.

\section{CONCLUSION}

After decades of progress in desegregating America's schools, we as a society are turning our backs on the policy of school desegregation despite both the academic, economic, and social benefits of attending desegregated schools documented by social science research, and the fact that the overwhelming majority of both Whites and African-Americans report favoring diverse schools. Reasons for the waning popularity of attempts to actually bring about desegregation are many and diverse. Understanding such reasons may help guide us through a post-desegregation era in which we will meet the challenges of increasingly segregated schools once again. Understanding why desegregation as a policy fell out of favor in our society may offer important insights into how to devise additional means of ensuring equality of education for all children in the future. 


\section{REFERENCES}

Abney, E. E. (1980). A comparison of the status of Florida's Black public school principals, 1964-65/1975-76. The Journal of Negro Education, 49, 398-406.

Achilles, C. M. (2002). Racial disparities in school discipline. In C. H. Rossell, D. J. Armor, \& H. J. Walberg(Eds.), School desegregation in the 21st century (pp. 235-265). Westport, CT: Praeger.

Adair, A. V. (1984). Desegregation: The illusion of Black progress. Lanham, MD: University Press of America.

Armor, D. J. (1972). The evidence on busing. Public Interest, 28, 90-124.

Armor, D. J. (1984). The evidence on desegregation and Black achievement. In T. Cook, D. Armor, R. Crain, N. Miller, W. Stephan, H. Walberg et al. (Eds.), School desegregation and Black achievement (pp. 43-67). Washington, DC: National Institute of Education.

Armor, D. J. (1995). Forced justice: School desegregation and the law. New York: Oxford University Press.

Artiles, A. J., Trent, S. C., \& Palmer, J. D. (2004). Culturally diverse students in special education. In J. A. Banks \& C. A. McGee Banks (Eds.), Handbook of research on multicultural education (2nd ed., pp. 716-735). New York: John Wiley \& Sons.

Baron, J., \& Norman, F. M. (1992). SATs, achievement tests, and high-school class rank as predictors of college performance. Educational and Psychological Measurement, 52, 1047-1055.

Bell, D. A. (1989a). And we are not saved: The elusive quest for racial justice. New York: Basic Books.

Bell, D. A. (1989b). The case for a separate Black school system. In W. D. Smith \& E. W. Chunn (Eds.), Black education: A quest for equity and excellence (pp. 136-145). New Brunswick, NJ: Transaction Publishers.

Bell, D. A. (1980). Shades of Brown: New perspectives on school desegregation, New York: Teachers College Press.

Bickle, K., Hakuta, K., \& Billings, E. S. (2004). Trends in two-way immersion research. In J. A. Banks \& C. A. McGee Banks (Eds.), Handbook of research on multicultural education (2nd ed., pp. 589-604). New York: John Wiley \& Sons.

Bennett, A., \& Easton, J. Q. (1988, April). Voluntary transfer and student achievement: Does it help or hurt? Paper presented at the meeting of the American Educational Research Association, New Orleans. 
Blauner, R. (1989). Black lives, White lives: Three decades of race relations in America. Berkeley: University of California Press.

Boateng, F. (1990). Combatting deculturalization of the African-American child in the public school system: A multicultural approach. In K. Lomotey (Ed.), Going to school: The African-American experience (pp. 73-84). Albany: State University of New York Press.

Bobo, L., \& Kluegel, J. R. (1993). Opposition to race-targeting: Self-interest, stratification ideology, or racial attitudes. American Sociological Review, 58, 443-464.

Boozer, M. A., Krueger, A. B., Wolkon, S., Haltiwanger, J. C., \& Loury, G. (1992). Race and school quality since Brown v. Board of Education. Brookings Papers on Economic Activity. Microeconomics, 269-338. Retrieved on May 13, 2004 from http://www.jstor.org.

Braddock, J. H., II (1985). School desegregation and Black assimilation. Journal of Social Issues, 41(3), 9-22.

Braddock, J. H., II (1987, June). Segregated high school experiences and Black students' college and major field choices. Paper presented at the National Conference on School Desegregation, Chicago.

Braddock, J. H., II, Crain, R. L., \& McPartland, J. M. (1984). A long-term view of school desegregation: Some recent studies of graduates as adults. Phi Delta Kappan, 66, 259-264.

Braddock, J. H., II, Crain, R. L., McPartland, J. M., \& Dawkins, M. P. (1986). Applicant race and job placement decisions: A national survey experiment. Journal of Sociology and Social Policy, 6, 3-24.

Braddock, J. H., II, \& Eitle, T. M. (2004). The effects of school desegregation. In J. A. Banks \& C. A. McGee Banks (Eds.), Handbook of research on multicultural education (2nd ed., pp. 828-846). New York: John Wiley $\&$ Sons.

Braddock, J. H., II, \& McPartland, J. M. (1982). Assessing school desegregation effects: New directions in research. In R. Corwin (Ed.), Research in sociology of education and socialization (Vol. 3, pp. 259-282). Greenwich, CT: JAI Press.

Braddock, J. H., II, \& McPartland, J. M. (1983). More evidence on social-psychological processes that perpetuate minority segregation: The relationship of school desegregation and employment segregation (Report No. 338). Baltimore, MD: Johns Hopkins University, Center for Social Organization of Schools.

Braddock, J. H., II, \& McPartland, J. M. (1987). How minorities continue to be excluded from equal employment opportunities: Research on labor market and institutional barriers. Journal of Social Issues, 43, 5-39. 
Braddock, J. H., II, \& McPartland, J. M. (1989). Social-psychological processes that perpetuate racial segregation: The relationship between school and employment desegregation. Journal of Black Studies, 19, 267-289.

Braddock, J. H., II, McPartland, J. M., \& Trent, W. (1984, April). Desegregated schools and desegregated work environments. Paper presented at the meeting of the American Educational Research Association, New Orleans.

Bradley, L. A., \& Bradley, G. W. (1977). The academic achievement of Black students in desegregated schools: A critical review. Review of Educational Research, 47, 399-449.

Brown, K. (1996). Revisiting the Supreme Court's opinion in Brown v. Board of Education from a multiculturalist perspective. In E. Lagemann \& L. P. Miller (Eds.), Brown v. Board of Education: The challenge for today's schools (pp. 44-53). New York: Teachers College Press.

Brown v. Bd. of Educ., 347 U.S. 483 (1954).

Brown v. Bd. of Educ., 349 U.S. 294 (1955).

Bryant, J. C. (1968). Some effects of racial integration of high school students on standardized achievement test scores: Teacher grades and drop-out rates in Angleton, Texas. Unpublished doctoral dissertation, University of Houston.

Caldas, S. J., \& Bankston, C. (1998). The inequality of separation: Racial composition of schools and academic achievement. Educational Administration Quarterly, 34, 553-557.

Carsrud, K. B. (1984). Does pairing hurt Chapter 1 students? Austin, TX: Austin Independent School District, Office of Research and Evaluation.

Carter, D. G. (1982). Second-generation school integration problems for Blacks. Journal of Black Studies, 13, 175-188.

Chunn, E. W. (1989). Sorting Black students for success and failure: The inequity of ability grouping and tracking. In W. D. Smith \& E. W. Chunn (Eds.), Black education: A quest for equity and excellence (pp. 93-106). New Brunswick, NJ: Transaction Publishers.

Cook, S. W. (1979). Social science and school desegregation: Did we mislead the Supreme Court? Personality and Social Psychology Bulletin, 5, 420-437.

Cook, T. D. (1984). What have Black children gained academically from school integration?: Examination of the meta-analytic evidence. In T. Cook, D. Armor, R. Crain, N. Miller, W. Stephan, H. Walberg, \& P. Wortman (Eds.), School desegregation and Black achievement (pp. 6-42). Washington, D.C.: National Institute of Education. 
Crain, R. L. (1970). School integration and occupational achievement of Negroes. American Journal of Sociology, 75, 593-606.

Crain, R. L. (1984a). Is nineteen really better than ninety-three? Washington, D.C.: National Institute of Education.

Crain, R. L. (1984b). The quality of American high school graduates: What employers say and do about it. (Rep. No. 354). Baltimore, MD: Center for the Social Organization of Schools, Johns Hopkins University.

Crain, R. L., \& Mahard, R. E. (1978). School racial composition and Black college attendance and achievement test performance. Sociology of Education, 51, 81-101.

Crain, R. L., Miller, R. L., Hawes, J. A., \& Peichert, J. R. (1992). Finding niches: Desegregated students sixteen years later. Final report on the educational outcomes of Project Concern, Hartford, Connecticut. Institute for Urban and Minority Education. Teachers College, Columbia University.

Crain, R. L., \& Strauss, J. (1985). School desegregation and Black occupational attainments: Results from a long-term experiment (Rep. No. 359). Baltimore: Center for the Social Organization of Schools.

Crain, R. L., \& Weisman, C. S. (1972). Discrimination, personality, and achievement; A survey of Northern Blacks. New York: Seminar Press.

Dawkins, M. P. (1983). Black students' occupational expectations: A national study of the impact of school desegregation. Urban Education, 18, 98-113.

Dawkins, M. P. (1991). Long-term effects of school desegregation on AfricanAmericans: Evidence from the National Survey of Black Americans. Unpublished manuscript.

Days, D. S. (1992). Brown blues: Rethinking the integrative ideal. William and Mary Law Review, 34, 53-74.

Dempsey, V., \& Noblit, G. W. (1993). Cultural ignorance and school desegregation: Reconstructing a silenced narrative. Educational Policy, 7, 318-339.

Dowell v. Bd. of Educ., 498 U.S. 237 (1991).

Ehrlander, M. F. (2002). Equal educational opportunity: Brown's elusive mandate. New York: LFB Scholarly Publishing.

Erbe, B. M. (1977). Comments and letters: On the "politics of school busing." Public Opinion Quarterly, 41, 113-117.

Ethridge, S. B. (1979). Impact of the 1954 Brown vs. Topeka Board of Education decision on Black educators. The Negro Educational Review, $30,217-232$. 
Falk, W. W. (1978). Mobility attitudes of segregated and desegregated Black youths. Journal of Negro Education, 3, 132-142.

Feagin, J. R. (2000). Racist America: Roots, current realities, and future reparations. New York: Routledge.

Fleming, J. (2002). Who will succeed in college? When the SAT predicts Black students' performance. The Review of Higher Education, 25, 281-296.

Fleming, J., \& Garcia, N. (1998). Are standardized tests fair to AfricanAmericans? Predictive validity of the SAT in Black and White institutions. The Journal of Higher Education, 69, 471-495.

Ford, D. Y. (1995). Desegregating gifted education: A need unmet. The Journal of Negro Education, 64, 52-62.

Frankenberg, E., Lee, C., \& Orfield, G. (2003). A multiracial society with segregated schools: Are we losing the dream? Harvard Civil Rights Project. Retrieved May 10, 2004 from http://www.civilrightsproject. harvard.edu/research/reseg03/reseg03_full.php.

Freeman v. Pitts, 503 U.S. 467 (1992).

Gable, R. K., \& Iwanicki, E. F. (1986). The longitudinal effects of a voluntary school desegregation program on the basic skill progress of participants. Metropolitan Education, 1, 76-77.

Gable, R. K., Thompson, D. L., \& Iwanicki, E. F. (1983). The effects of voluntary desegregation on occupational outcomes. The Vocational Guidance Quarterly, 31, 230-239.

Gatlin, D. S., Giles, M. W., \& Cataldo, E. F. (1978). Policy support within a target group: The case of school desegregation. The American Political Science Review, 72, 985-995.

Geiser, S., \& Studley, R. (2002). UC and the SAT: Predictive validity and differential impact of the SAT I and SAT II at the University of California. Educational Assessment, 8, 1-26.

Gibson, C., \& Jung, K. (2002). Historical census statistics on population totals by race, 1970 to 1990 , and by Hispanic origin, 1920 to 1990 , for the United States, regions, divisions, and states. Working paper No. 56, Population Division, U.S. Census Bureau, Washington, D.C. Retrieved June 11, 2004 from http://www.census.gov/population/www/socdemo/ race.html.

Goetz, J. P., \& Breneman, E. A. (1988). Desegregation and Black students' experiences in two rural southern elementary schools. The Elementary School Journal, 88, 489-502.

Green, D. P., \& Cowden, J. A. (1992). Who protests: Self-interest and White opposition to busing. The Journal of Politics, 54, 471-496. 
Grogger, J. (2001). Does school quality explain the recent Black/White wage trend? Journal of Labor Economics, 14, 231-253.

Harris, I. M. (1983). The inequities of Milwaukee's plan. Integrated Education, 21, 173-177.

Heleen, O. (Ed.). (1987). Two-way bilingual education: A strategy for equity [Special issue]. Equity and Choice, 3(3).

Hoelter, J. W. (1982). Segregation and rationality in Black status aspiration process. Sociology of Education, 55, 31-39.

Hudson, M. J., \& Holmes, B. J. (1994). Missing teachers, impaired communities: The unanticipated consequences of Brown v. Board of Education on the African-American teaching force at the pre-collegiate level. The Journal of Negro Education, 63, 388-393.

Jencks, C., Smith, M., Acland, H., Bane, M. J., Cohen, D., Gintis, H. et al. (1972). Inequality. New York: Basic Books.

Johnson, D. A. (1990). The relationship between school integration and student attitude toward residential racial integration. Dissertation Abstracts International, 51, 25-27.

Johnson, A. M. (1993). Bid whist, tonk, and United States v. Fordice: Why integrationism fails African-Americans again. California Law Review, 81, 1401-1470.

Kelley, J. (1974). The politics of school busing. Public Opinion Quarterly, 38, 22-39.

Kinder, D. R., \& Rhodebeck, L. A. (1982). Continuities in support for racial equality, 1972 to 1976. Public Opinion Quarterly, 46, 195-215.

Kinder, D. R., \& Sears, D. O. (1981). Prejudice and politics: Symbolic racism versus racial threats to the good life. Journal of Personality and Social Psychology, 40, 414-431.

Kluegel, J. R. (1990). Trends in Whites' explanations of the Black-White gap in socioeconomic status, 1977-1989. American Sociological Review, 55, 512-525.

Kluegel, J. R., \& Smith, E. R. (1982). Whites' beliefs about Blacks' opportunity. American Sociological Review, 47, 518-532.

Krol, R. A. (1978). A meta-analysis of comparative research on the effects of desegregation on academic achievement. Unpublished doctoral dissertation, Western Michigan University. (University Microfilms No. 79-07962).

Lomotey, K., \& Fossey, R. (1997). School desegregation: Why it hasn't worked and what could work. In C. Teddlie \& K. Lomotey (Co-Eds.), Forty years after the Brown decision: Social and cultural effects of school desegregation (pp. 401-419). New York: AMS Press. 
Mahard, R. E., \& Crain, R. L. (1983). Research on minority achievement in desegregated schools. In C. H. Rossell \& W. D. Hawley (Eds.), The consequences of school desegregation (pp. 103-125). Philadelphia: Temple University Press.

Marston, A. R. (1971). It is time to reconsider the Graduate Record Examination. American Psychologist, 26, 653-655.

McClelland, D. C. (1973). Testing for competence rather than for intelligence. American Psychologist, 28, 1-14.

McClendon, M. J. (1985). Racism, rational choice, and White opposition to racial change: A case study of busing. Public Opinion Quarterly, 49, 214-233.

McConahay, J. B. (1982). Self-interest versus racial attitudes as correlates of anti-busing attitudes in Louisville: Is it the buses or the Blacks? Journal of Politics, 44, 692-720.

McConahay, J. B. (1986). Modern racism, ambivalence, and the modern racism scale. In J. F. Dovidio \& S. L. Gaertner (Eds.), Prejudice, discrimination, and racism (pp. 91-125). Orlando, FL: Academic Press.

McCullough-Garrett, A. (1993). Reclaiming the African-American vision for teaching: Toward an educational conversation. The Journal of Negro Education, 62, 433-440.

McMiller, D. L. (2000). Public opinion and school desegregation in Hartford, Connecticut. Equity \& Excellence in Education, 33, 68-80.

McPartland, J. M., \& Crain, R. L. (1980). Racial discrimination, segregation, and processes of social mobility. In V. T. Covello (Ed.), Poverty and public policy (pp. 97-125). Boston: Schenkman.

Mickelson, R. A. (2001). Subverting Swann: Tracking and second generation segregation in Charlotte-Mecklenburg schools. American Educational Research Journal, 38(2), 215-252.

Miller, L. S. (1995). An American imperative: Accelerating minority educational advancement. New Haven, CT: Yale University Press.

Miller, N., \& Carlson, M. (1984). School desegregation as a social reform: A meta-analysis of its effects on Black academic achievement. In T. Cook, D. Armor, R. Crain, N. Miller, W. Stephan, H. Walberg et al. (Eds.), School desegregation and Black achievement (pp. 89-130). Washington, D.C.: National Institute of Education.

Noblit, G. W., \& Collins, T. W. (1981). Qui bono? White students in a desegregated high school. The Urban Review, 13, 205-216.

Ogbu, J. U. (2003). Black American students in an affluent suburb: A study of academic disengagement. Mahwah, NJ: Erlbaum. 
Orfield, G. (1978). Must we bus? Segregated schools and national policy. Washington, D.C.: The Brookings Institution.

Orfield, G. (2001). Schools more separate: Consequences of a decade of resegregation. The Civil Rights Project. Harvard University. Retrieved May 10, 2004, from http://www.civilrightsproject.harvard.edu/research/ deseg/Schools_More_Separate.pdf.

Orfield, G., \& Eaton, S. E. (1996). Dismantling desegregation: The quiet reversal of Brown v. Board of Education. New York: The New Press.

Patchen, M. (1982). Black-White contact in schools: Its social and academic effects. West Lafayette, IN: Purdue University Press.

Plessy v. Ferguson, 163 U.S. 537 (1896).

Pride, R., \& Woodward, D. (1985). The burden of busing: The politics of desegregation in Nashville, Tennessee. Knoxville: University of Tennessee Press.

Reardon, S. F., \& Yun, J. T. (2003). Integrating neighborhoods, segregating schools: The retreat from school desegregation in the south, 1990-2000. North Carolina Law Review, 81, 1563-1596.

Rist, R. C. (1978). The invisible children: School integration in American society. Cambridge, MA: Harvard University Press.

Rosenbaum, J. E. (1995). Changing the geography of opportunity by expanding residential choice: Lessons from the Gautreaux Program. Housing Policy Debate, 6, 231-269.

Rossell, C. H. (1990). The carrot or the stick for school desegregation policy: Magnet schools or forced busing? Philadelphia: Temple University Press.

Rossell, C. H. (1995). The convergence of Black and White attitudes on school desegregation issues during the four decade evolution of the plans. William and Mary Law Review, 36, 613-663.

Rumberger, R. W., \& Palardy, G. J. (2003). Does segregation (still) matter? The impact of student composition on academic achievement in high school. Manuscript submitted for publication.

Savage, C. J. (2001). "Because we did more with less": The agency of African-American teachers in Franklin, Tennessee: 1890-1967. Peabody Journal of Education, 76, 170-203.

Schofield, J. W. (1989). Black and white in school: Trust tension or tolerance? New York: Teachers College Press.

Schofield, J. W. (1991). School desegregation and intergroup relations: A review of the literature. In G. Grant (Ed.), Review of research in education (pp. 335-409). Washington, D.C.: American Educational Research Association. 
Schofield, J. W. (1995). Review of research on school desegregation's impact on elementary and secondary school students. In J. A. Banks \& C. A. McGee Banks (Eds.), Handbook of research on multicultural education (pp. 597-617). New York: MacMillan.

Schofield, J. W. (2004a). Fostering positive intergroup relations in schools. In J. A. Banks \& C. A. McGee Banks (Eds.), Handbook of research on multicultural education (2nd ed., pp. 799-812). New York: John Wiley \& Sons.

Schofield, J. W. (2004b). The colorblind perspective in school: Causes and consequences. In J. A. Banks \& C. A. McGee Banks (Eds.), Multicultural education: Issues and Perspectives (5th ed., pp. 265-288). New York: John Wiley \& Sons.

Schuman, H., \& Krysan, M. (1999). A historical note of Whites' beliefs about racial inequality. American Sociological Review, 64, 847-855.

Schuman, H., Steeh, C., Bobo, L., \& Krysan, M. (1997). Racial attitudes in America: Trends and Interpretations. Cambridge, MA: Harvard University Press.

Sears, D. O., Van Laar, C., Carrillo, M., \& Kosterman, R. (1997). Is it really racism?: The origins of White Americans' opposition to race-targeted policies. Public Opinion Quarterly, 61, 16-53.

Sears, D. O., Hensler, C. P., \& Speer, L. K. (1979). Whites' opposition to "busing": Self-interest or symbolic politics? The American Political Science Review, 73, 369-384.

Sears, D. O., Lau, R. R., Tyler, T. R., \& Allen, H. M. (1980). Self-interest vs. symbolic politics in policy attitudes and presidential voting. The American Political Science Review, 74, 670-684.

Sheff v. O’Neill, 678 A.2d 1267 (Conn. 1996).

Singer, H., Gerard, H. B., \& Redfearn, D. (1975). Achievement. In H. B. Gerard \& N. Miller (Eds.), School desegregation: A long-range study (pp. 69-87). New York: Plenum Press.

Stephan, W. G. (1978). School desegregation: An evaluation of predictions made in Brown v. Board of Education. Psychological Bulletin, 85, 217-238.

Stephan, W. G. (1984). Blacks and Brown: The effects of school desegregation on Black students. In T. Cook, D. Armor, R. Crain, N. Miller, W. Stephan, H. Walberg et al. (Eds.), School desegregation and Black achievement (pp. 131-159). Washington, DC: National Institute of Education.

St. John, N. H. (1975). School desegregation: Outcomes for children. New York: Wiley. 
Trent, W. T. (1991). Desegregation analysis report. New York: The Legal Defense and Educational Fund.

Trent, W. T. (1997). Outcomes of school desegregation: Findings from longitudinal research. The Journal of Negro Education, 66, 255-257.

United States Kerner Commission (1968). Report of the National Advisory Commission on Civil Disorders. New York: New York Times.

Vardi, M. Y., Finin, T., \& Henderson, T. (March, 2003). 2001-2002 Taulbee survey: Survey results show better balance in supply and demand. Computing Research News, 6-13.

Walberg, H. J. (1984). Desegregation and education productivity. In T. Cook, D. Armor, R. Crain, N. Miller, W. Stephan, H. Walberg et al. (Eds.), School Desegregation and Black Achievement (pp. 160-193). Washington, DC: National Institute of Education.

Walker, V. S. (1996). Their highest potential: An African-American School Community in the Segregated South. Chapel Hill: University of North Carolina Press.

Weinberg, M. (1977). Minority Students: A research Appraisal. Washington, DC: National Institute of Education.

Wells, A. S. (1995). Reexamining social science research on school desegregation: Long-versus short-term effects. Teachers College Record, 96, 691-706.

Wells, A. S., \& Crain, R. L. (1994). Perpetuation theory and the long-term effects of school desegregation. Review of Educational Research, 64, 531-555.

Wells, A. S., \& Crain, R. L. (1997). Stepping over the color line: AfricanAmerican students in White suburban schools. New Haven: Yale University Press.

Williams, D. R., Jackson, J. S., Brown, T. N., Torres, M., Forman, T. A., \& Brown, K. (1999). Traditional and contemporary prejudice and urban Whites' support for affirmative action and government help. Social Problems, 46, 503-527.

Wilson, G., \& Braddock, J. (1997). Analyzing racial ideology: Post-1980 America. In E. M. Kramer (Ed.), Postmodernism and race (pp. 129-143). Westport, CT: Praeger.

Wood, P. B., \& Sonleitner, N. (1996). The effect of childhood interracial contact on adult anti-Black prejudice. International Journal of Intercultural Relations, 20, 1-17.

Wortman, P. M. (1984). School desegregation and Black achievement: An integrative view. In T. Cook, D. Armor, R. Crain, N. Miller, W. Stephan, 
H. Walberg et al. (Eds.), School desegregation and Black achievement (pp. 194-224). Washington, DC: National Institute of Education. 